\title{
1. Investigating intellectual capital disclosure through content analysis: reflections and suggestions for future research

\author{
Laura Bini and Francesco Giunta
}

\section{BEYOND THE INTELLECTUAL CAPITAL STATEMENT: INTEGRATED REPORTS AND NON-FINANCIAL INFORMATION REGULATIONS}

Over the years, the importance of intellectual capital has increased. Thus, when considering the value creation process, managers have shifted their focus from tangible to intangible capital (Abeysekera, 2006). This shift has also affected corporate reporting, which emphasizes intellectual capital disclosure.

Researchers have put considerable effort into developing an adequate framework for intellectual capital reporting. Starting from the early 2000s, many studies have focused on the measuring and reporting of intangibles. The Guidelines proposed by the Measuring Intangibles to Understand and Improve Innovation Measurement (MERITUM) (2002) project funded by the European Union (EU), and the final document of the Intellectual Capital Statement Project (Mouritsen et al., 2003), founded by the Danish Ministry of Science, Technology and Innovation, are considered as two seminal works. Academics in the field consider that these frameworks have failed to achieve their goals and they have not produced any significant change in financial accounting rules (Canibano, 2018; Schaper et al., 2017). Indeed, it is said that 'intellectual capital reporting appears to have died for listed companies', because companies have actually stopped preparing intellectual capital reports since 2011 (Dumay, 2016, p. 168).

While intellectual capital reports have gradually disappeared, a growing number of listed companies have started to voluntarily publish an integrated report. According to its proponents, the integrated report is 'a concise communication about how an organization's strategy, governance, performance and prospects, in the context of its external environment, lead to the creation of value over the short, medium and 
long term' (IIRC, 2013b, p. 7). In 2013, the International Integrated Reporting Council (IIRC) issued an IR Framework that has become the most used guideline for the preparation of an integrated report. The IR Framework identifies six different capitals a company needs to report on in order to provide stakeholders with a full picture of a company's value creation process.

The ongoing development of the integrated report offers interesting opportunities for intellectual capital disclosure research for a number of reasons. First of all, the IR Framework includes the publication of intellectual capital information. Three of the six capitals proposed in the IR Framework are closely related to intangible factors that are considered as major constituents of intellectual capital (Sveiby, 1997; Guthrie and Petty, 2000; Bontis, 2003): (1) intellectual capital, which includes both intellectual properties and tacit knowledge, systems, procedures and protocols; (2) human capital, which focuses on people's competencies, capabilities and experience, and their motivations to innovate; and (3) social and relationship capital, which deals with the relationships within and between communities, groups of stakeholders and other networks (IIRC, 2013b). Second, it seems that the integrated report is becoming one of the preferred channels for companies to disclose intellectual capital. The IR Framework has currently been tested in over 25 countries (IIRC, 2013a), and the number of companies regularly publishing an integrated report is increasing over time (Dilling and Harris, 2018). Lastly, integrated reporting is the subject of lively debate with conflicting positions. Proponents of integrated reporting believe that this document represents a radical innovation for corporate reporting, an opportunity to 'rethink the role of business and the interrelatedness of all its activities' (Painter-Morland, 2006, p. 363). They argue that integrated reporting is an essential requirement to achieve a more sustainable economy and greater accountability and transparency at a corporate level (Eccles and Krzus, 2010; IIRC, 2013b). The multiple capital model of the IR Framework is expected to shift the focus from meeting short-term financial goals to developing a long-term business strategy (Eccles and Krzus, 2010; Adams, 2015).

On the other hand, those who are sceptical about the opportunities related to integrated reporting advocate that beyond a well-established rhetorical infrastructure that emphasizes the benefits of integrated reporting, very little research has been conducted to assess the impact of integrated reporting and demonstrate the expected advantage of adopting such a framework (Flower, 2015; Dumay et al., 2016; Dumay, 2016; Maniora, 2017). It is also argued that the IR Framework only consists of general principles and provides little guidance on some crucial 
issues, such as the definition of value creation or the measurement of intangibles (Cheng et al., 2014). Certainly, these different positions call for research to clarify whether integrated reporting is a fashionable trend or whether it could play a major role in influencing corporate reporting practices.

Along with the development of voluntary intellectual capital disclosure practices, both national and international legislators have introduced new reporting regulations on non-financial information, which strongly relates to intellectual capital. For instance, companies are requested to disclose increasing amounts of information concerning employee-related matters, which are very close to the human capital pillar proposed in the intellectual capital reporting frameworks. Specific requirements on social and environmental matters, which are aligned with the relational capital pillar, have also been introduced. Lastly, the regulation about corporate governance systems, which are 'themselves systems of intellectual capital' (Keenan and Aggestam, 2001), has been widely strengthened.

In 2006, the United Kingdom (UK) standard setter issued a guideline for companies to prepare a management commentary (Operating and Financial Review). The guideline stated that companies should:

set out the key strengths and resources, tangible and intangible, available to the business, which will assist it in the pursuit of its objective and, in particular, those items that are not reflected in the balance sheet. Depending on the nature of the business, these may include: corporate reputation and brand strength; natural resources; employees; research and development; intellectual capital; licences, patents, copyright and trademarks; and market position. (Accounting Standards Board, 2006, p. 51)

More recently, the European Union has issued Directive 2014/95, which obliges all large companies operating in an EU member country to disclose non-financial information in their annual reports. The set of nonfinancial items that the EU Directive requires includes environmental, social and employee matter; respect for human rights; and anti-corruption and bribery matters.

The introduction of these initiatives offers new research opportunities. These include the challenges posed by the regulation of intellectual capital information compared to financial information, as well as the identification of the qualitative characteristics associated to the reliability and the materiality of intellectual capital information, and the evaluation of the effects caused by a mandatory regime. 


\section{USING CONTENT ANALYSIS IN INTELLECTUAL CAPITAL DISCLOSURE RESEARCH}

\section{Content Analyses in Intellectual Capital Disclosure Research}

Since intellectual capital disclosure is largely narrative in nature, content analysis is considered an appropriate method for investigation (Beattie and Thomson, 2007; Husin et al., 2012). Content analysis is a systematic method of identifying specific characteristics through the association of words with categories of the business environment, strategy, operations, human resources, and others, to build a classification scheme (Krippendorff, 2013).

Although content analysis is well established in the intellectual capital disclosure field of research, much criticism has been levelled against its use in previous studies. Beattie and Thomson (2007, p. 131) complain of 'a general lack of transparency in the content analysis methods used in the intellectual capital disclosure studies to date', while Dumay and Cai (2014, 2015) point out the conflicting results and call for more methodological precision to overcome inconsistencies. Lastly, Abeysekera (2006, p. 71) notes several issues that 'need to be resolved in order for intellectual capital disclosure research to be improved'.

The next section illustrates the principal phases that substantiate a content analysis, and considers some of the critical issues that have often been underestimated in previous studies, techniques that have not received substantial attention so far, and what might represent future research opportunities.

\section{Investigating Intellectual Capital Disclosure in the Positive Paradigm}

Contrary to other research methodologies, data in content analysis is not under researcher control (Dumay and Cai, 2015). Thus, the texts included in the analysis need to be identified simultaneously with the definition of the research question and the theoretical framework (Krippendorff, 2013) (see Figure 1.1).

The coherence between the research paradigm framework and the type of content analysis employed is a critical issue. Positivism is the dominant paradigm in accounting narrative research, including intellectual capital disclosure (Merkl-Davies et al., 2011). This is due, at least in part, to the fact that corporate intellectual capital disclosure is often explained by agency theory, a theoretical framework that mirrors a classical positivist approach. According to this framework, managers use intellectual capital disclosure as a mechanism to reduce investor uncertainty relating to the impact of intellectual capital on the firm's value (Welker, 1995). Therefore, 


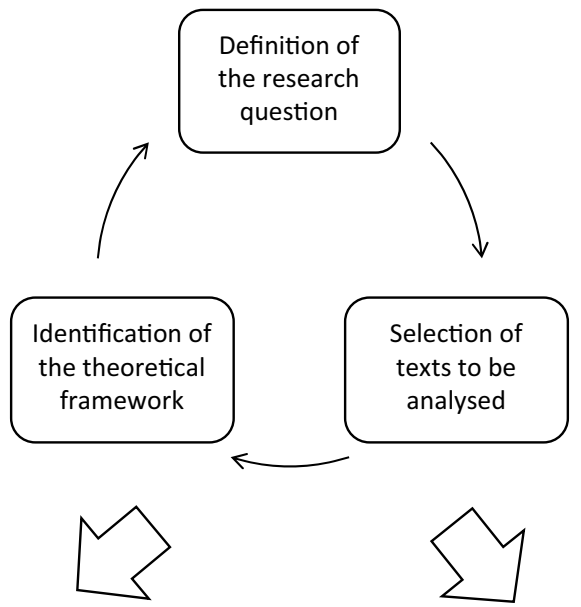

FORM-ORIENTED CONTENT ANALYSIS

MEANING-ORIENTED CONTENT ANALYSIS
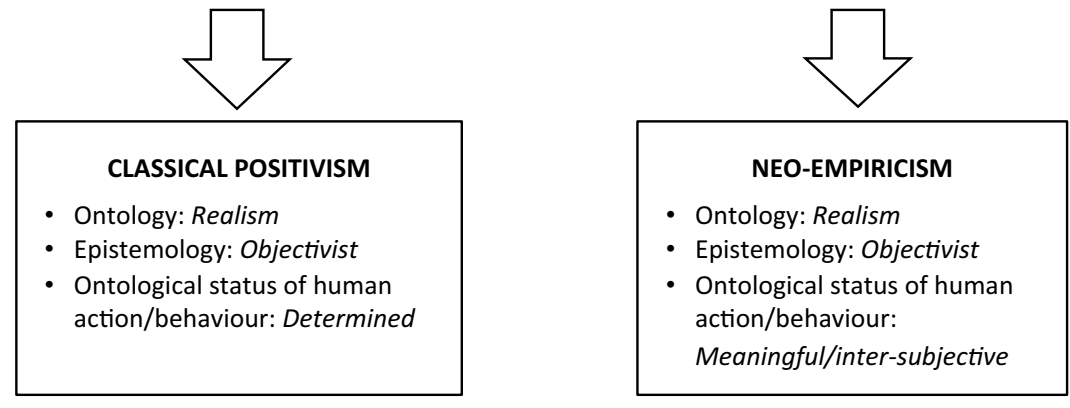

Source: Authors' elaboration based on Merkl-Davies et al. (2011).

Figure 1.1 Content analysis and research paradigms

high intellectual capital disclosure is expected to provide a more intensive monitoring package for a firm to reduce opportunistic behaviour and information asymmetry (Li et al., 2008). Studies adopting this framework usually use content analysis to assess the amount of intellectual capital disclosure and verify its association with information asymmetries or other company characteristics (Li et al., 2008; Whiting and Woodcock, 2011).

Positivism is characterized by a realist ontology, which states that social reality has an independent existence prior to human cognition, and an objectivist epistemology, assuming that the properties of the social reality can be measured through objective methods (Johnson and 
Duberley, 2000). However, within the positivist paradigm, differences can be found in the beliefs regarding the ontological status of human action/ behaviour (Jackson and Carter, 1993). In classical positivism, human action/behaviour is regarded as objective: that is, rational, purposeful and goal-oriented. In contrast, neo-empiricism considers the behaviour of organizational actors as subjective: that is, they act symbolically by attributing meaning to organizational outcomes and events (Boland and Pondy, 1983). As a result, under classical positivism, content analysis studies aim to produce objective evidence to be used for hypothesis testing. In contrast, in neo-empiricism content analysis objectively captures how organizational actors construct meanings, focusing on underlying themes in the texts (Merkl-Davies et al., 2011).

The choice between research paradigms noticeably influences the development of a content analysis study. Researchers who adopt a classical positivist framework perform the so-called 'form-oriented' analysis (Smith and Taffler, 2000). This analysis aims to convert narratives into numerical scores or indices 'to draw statistical inferences about the types and intent' of narrative disclosures (Craig et al., 2010). Thus, content analysis converts proxies for organizational disclosure behaviour into thematic or semantic indices (Pollach, 2012). Then, indices are used to investigate, by means of statistical tests, the characteristics of intellectual capital disclosure (Bozzolan et al., 2003; Vandemaele et al., 2005), its determinants (Brüggen et al., 2009; Kamath, 2017) and its relevance (Chen et al., 2005; Vafaei et al., 2011).

Melloni (2015), for instance, uses form-oriented content analysis to investigate intellectual capital disclosure within integrated reporting, positing two research questions, on how firms offer intellectual capital disclosure in integrated reports, and whether they resort to impression management strategies in doing this. The evidence of content analysis is used to calculate a disclosure index concerning the tone of disclosure, by means of which each company is graded with a score. This index is then used in a statistical test to verify the association of the tone of disclosure with several variables that are considered as incentives to manipulate disclosure.

Content analyses can be used in the classical positivist paradigm to test hypotheses that have been deductively stated before, but also in the neo-empiricist paradigm (Alvesson and Deetz, 2000). In this case, the goal is 'to develop inductively thick descriptions of the patterns in the intersubjective meanings that actors use to make sense of their everyday worlds and who investigate the implications of those interpretations for social interaction' (Johnson et al., 2006). In these contexts, content analysis is referred to as 'meaning-oriented' content analysis (Smith and Taffler, 2000), as outlined in Figure 1.1. 
Abhayawansa and Guthrie (2014) use meaning-oriented content analysis to investigate the types of intellectual capital information that analysts consider important. Presenting their research design, the authors explain that 'meaning-oriented content analysis was performed whereby text units/information items were assigned to appropriate intellectual capital subcategories by gauging the meaning they convey with their context' (Abhayawansa and Guthrie, 2014, p. 71). The authors use the context within which the intellectual capital information is presented to infer why intellectual capital is important for analysts. For instance, they notice that analysts' references to the management team are generally 'forwardlooking, and emphasize management's potential future contributions'. This fact leads the authors to induce that analysts consider management quality as a surrogate for the quality of human capital and corporate governance.

Another example of meaning-oriented analysis is represented by Campbell and Rahman (2010), who conducted a longitudinal case study of intellectual capital disclosure to examine where external events may have driven changes in reporting patterns. The authors use meaning-oriented content analysis, first, to classify intellectual capital disclosure according to a preordained classification framework that divides intellectual capital disclosure into three categories (structural capital, relational capital and human capital). Then, each piece of information is coded to record 'the nature of the information (narrative or quantitative/financial) and the level of factuality or judgement conveyed by the information' (Campbell and Rahman, 2010, p. 62). The authors report an overall upward trend in purely narrative content and an overall downward trend in intellectual capital themes expressed as factual information. They interpret this finding in relation to the increasing complexity of the messages being conveyed, 'whereas physical assets can often be described in simple terms (the age of an asset, for example), intangibles are, by their nature, more complex to describe' (Campbell and Rahman, 2010, p. 67).

It is claimed that the utility of content analysis lies mainly in its meaning-oriented applications, which are able to make valid inferences about hidden or underlying meaning and messages of interest (Weber, 1990; Johnson et al., 2006). In keeping with this, Guthrie (2014) states that the importance of content analysis in intellectual capital disclosure research is mainly grounded in the fact that it brings understanding to issues that other methods cannot, especially by finding something hidden within the text. Despite this, intellectual capital disclosure studies mostly consist of form-oriented content analyses (Husin et al., 2012). Thus, meaning-oriented content analysis represents one of the most interesting areas of development for future research on intellectual capital disclosure 
(Merkl-Davies et al., 2011; Dumay and Cai, 2015). Marr and Chatzkel (2004, p. 227), for instance, call for 'rich, longitudinal case studies on intellectual capital disclosure that will allow us to understand the specific context which seems to be critical for the analysis of intellectual capital'.

\section{Developing a Content Analysis Procedure}

Content analysis used in the positivist paradigm is grounded in the assumptions of realist ontology and objectivist epistemology. This implies that the development of a content analysis framework (form-oriented or meaning-oriented) needs to follow a rigorous procedure in order to be accurate, precise, objective, reliable, replicable and valid (Berelson, 1952; Weber, 1990; Neuendorf, 2002; Krippendorff, 2013). Figure 1.2 illustrates the main steps of a content analysis design, according to Boyatzis (1998) and Weber (1990). Some critical issues concerning the phases in the content analysis procedure are presented and discussed below.

\section{Selection of the unit of analysis}

The first step in developing a content analysis procedure is to identify the unit of analysis. This requires selection of the section of a text used by

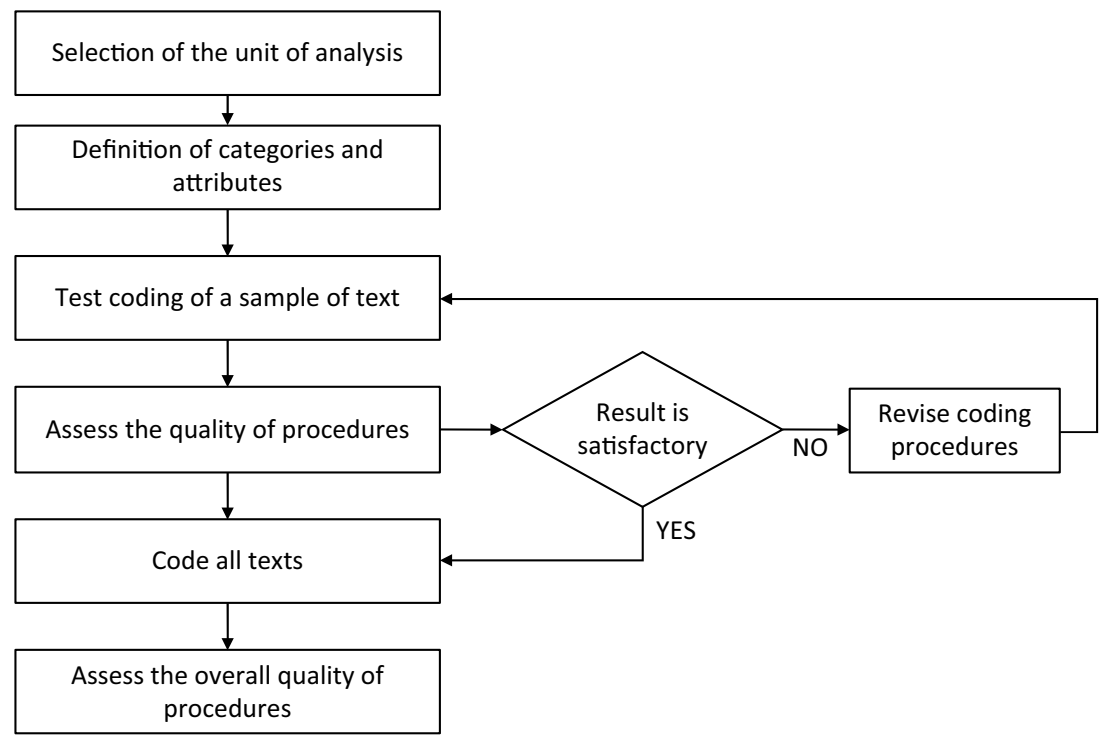

Source: Based on Boyatzis (1998) and Weber (1990).

Figure 1.2 Main steps in developing a content analysis 
researchers to code a text (Husin et al., 2012). Several units of analysis have been used to examine intellectual capital disclosure (words, sentences, paragraphs, themes, and so on), but none has become dominant because each unit has its own strengths and weaknesses. Therefore, the unit of analysis should be selected to minimize the subjectivity involved and take into account the characteristics of the examined texts. Abeysekera (2006) demonstrates that different units of analysis lead to different evidence using the same source documents.

Steenkamp and Northcott (2007) argue that larger units, for instance paragraphs, enhance the researcher's ability to capture contextual meaning, but they show some problems in terms of the mutual exclusivity of categories in the coding of text. On the contrary, smaller units, such as words or sentences, reduce the concerns related to mutual exclusivity of coding but 'tend to abstract the analysis unit from its surrounding context' (Steenkamp and Northcott, 2007, p. 17). Guthrie et al. (2004, p. 288) support paragraphs as the most suitable unit because 'people establish meaning based on paragraphs instead of particular words or a sentence'. However, Beattie and Thomson (2007) raise doubts about the use of paragraphs and sentences, because they increase the level of subjectivity in the analysis. Since information pertaining to different intellectual capital sub-categories can be disclosed within the same sentence, the authors argue that a decision has to be made in relation to the dominant intellectual capital sub-category. This decision gives rise to the need for other coding rules to identify dominant themes that increase the level of subjectivity in the analysis (Beattie and Thomson, 2007, p. 142). Despite these limitations, sentences are largely used as units of analysis in intellectual capital disclosure studies (Bozzolan et al., 2003; Vandemaele et al., 2005; Abeysekera and Guthrie, 2005; Whiting and Miller, 2008).

To overcome the limitations related to using sentences as a unit of analysis, some authors propose the use of text units (also called themes) (Holsti, 1969; Beattie and Thomson, 2007; Steenkamp and Northcott, 2007; Campbell and Rahman, 2010; Husin et al., 2012). According to Beattie et al. (2004, p. 216), a text unit is defined as each group of words containing a 'single piece of information that was meaningful in its own right'. Campbell and Rahman (2010) maintain that text units offer considerable advantages because they allow the totality of the narrative to be categorized without the constraints of allocating meaning by words, sentences or paragraphs. If a sub-category is reported in a small number of words, this can be captured just as effectively as if it were an entire paragraph. As a result, the total number of sub-categories described in an intellectual capital narrative can be effectively captured. 
However, since text units are not objectively identifiable like paragraphs and sentences, they need to be defined very clearly to minimize the subjectivity involved in the coding procedure (Steenkamp and Northcott, 2007). Carney (1972) recommends the use of illustrations to explain how text units are defined, rather than resorting to generalized, abstract terms.

The choice of the unit of analysis also depends on the use of an automated instead of a manual content analysis. Automated content analysis takes advantage of the development of specific software available since the 1980s. The use of automated content analysis may save time and effort, as the software makes it easier for researchers to conduct comprehensive analysis covering sizable samples (Abhayawansa, 2011). However, this is not a problem-free technique; for instance, automated coding processes are not able to recognize all possible synonyms and words with multiple meanings (Weber, 1990).

\section{Definition of categories and attributes}

The above-mentioned inconsistencies documented in intellectual capital disclosure studies (Dumay and Cai, 2015) are caused, at least in part, by the different coding procedures applied by researchers. The coding framework is the set of categories/taxonomies and the rules that support researchers in identifying and collecting target information within texts.

In the absence of an established definition of the intellectual capital concept, different intellectual capital frameworks have been developed over time (Abeysekera, 2006). Among these, the one elaborated by Guthrie et al. (2004) is the most well known. In keeping with Sveiby's (1997) classification of intellectual capital, Guthrie et al. (2004) renamed the categories (internal capital, external capital and human capital) and identified 18 separate intellectual capital attributes, six related to internal capital, seven to external capital and five to human capital (Table 1.1).

In reviewing the coding frameworks adopted in intellectual capital disclosure studies, Beattie and Thomson (2007) document a substantial agreement over the three categories of intellectual capital, but many discrepancies concerning specific intellectual capital attributes. They identified 128 different sub-categories that are used to describe the attributes that relate to the main three categories. Even if this long list includes synonyms, the authors argue that two main issues arise. The first issue concerns the broadness of the intellectual capital concept and the lack of an established definition; the second issue is a 'boundary' problem, as some attributes can be concurrently placed under different categories. Certainly, a more precise definition of the intellectual capital concept 


\section{Table 1.1 The intellectual capital coding framework}

\begin{tabular}{lll}
\hline Internal capital & External capital & Human capital \\
\hline Intellectual property & Brands & Employees \\
Management philosophy & Customers & Education \\
Corporate culture & Customer satisfaction & Training \\
Management processes & Company names & Work-related knowledge \\
Information/networking & Distribution channels & Entrepreneurial spirit \\
$\quad$ systems & Business collaborations & \\
Financial relations & Licensing agreements & \\
& & \\
\hline
\end{tabular}

Source: Authors' elaboration based on Guthrie et al. (2004).

could facilitate comparisons between findings, reducing inconsistencies (Striukova et al., 2008). However, Goebel (2015) documents that results of prior studies are comparable regarding rankings and key findings as long as most of the widely used intellectual capital items are included in prior intellectual capital research frameworks. Thus, although the categories in a coding framework should be defined according to the analysed texts and the research objectives (Weber, 1990), widely used intellectual capital items included in previous studies can provide a valuable reference to developing a comparable coding framework.

\section{Assess the quality of procedures}

Once the coding framework is defined, it is tested on a pilot sample until sufficient validity and reliability are achieved (Weber, 1990). This step is crucial to conform to underlying positivist assumptions: 'content analysts need to demonstrate the reliability of their instruments and/or the reliability of the data collected using those instruments to permit replicable and valid inferences to be drawn from data derived from content analysis' (Milne and Adler, 1999, p. 238) (see Figure 1.3).

Validity, on the one hand, focuses on 'how well results of a study mirror reality' (Merkl-Davies et al., 2011, p. 23). Validity concerns the sample and the methodological tools used in the analysis. Thus, a large and stratified sample guarantees higher validity in terms of the representativeness of a certain population and, consequently, of the generalizability of results. A thorough selection of categories that are good proxies for abstract phenomena may validate the interpretation of results. Clear and detailed coding rules reduce mistakes and bias among coders, increasing the validity of data collected (Weber, 1990). Finally, computer-assisted content analyses are associated with a higher level of validity than manual content 


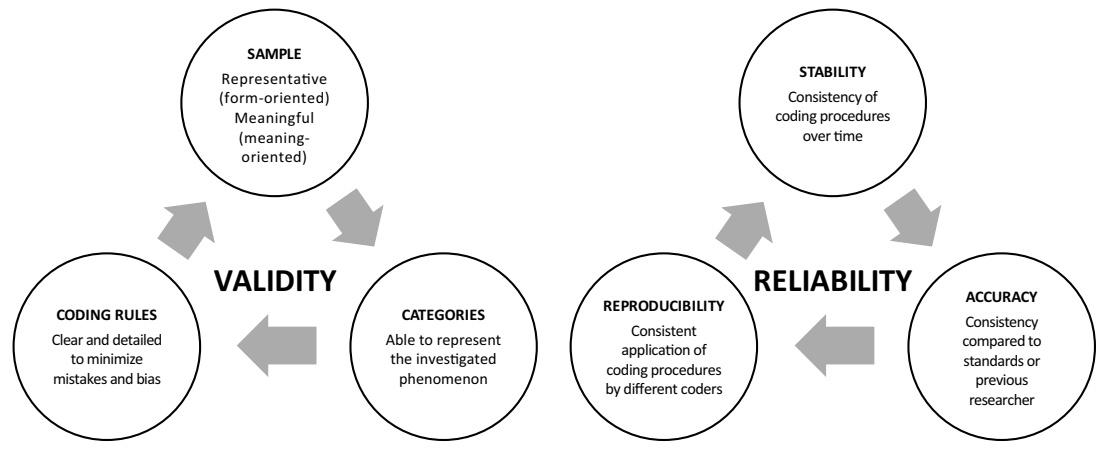

Source: Based on Weber (1990).

Figure 1.3 Evaluating a content analysis research design

analysis, as they reduce the presence of subjectivity and mistakes among collected data (Abrahamson and Park, 1994).

Reliability, on the other hand, 'is the extent to which data can be trusted to represent the phenomena of interest rather than spurious ones' (Krippendorff, 2013, p. 350). According to Krippendorff (2013), reliability deals with coding procedures adopted to content analyse texts. It consists of three different pillars: stability, reproducibility and accuracy. The first two pillars deal with the ability of a coding procedure to be consistently applied over time (stability) and by different coders (reproducibility). Accuracy 'involves assessing coding performance against a predetermined standard set' (Milne and Adler, 1999, p. 239), derived by previous literature or by a panel of experts.

Overall, these evaluation criteria are valid for both form-oriented and meaning-oriented content analyses, as both aim to permit replicable and valid inferences (Weber, 1990). However, some consideration should be given to specific points. Replicability and external validity (generalizability) issues in meaning-oriented content analysis and, more broadly, under neo-empiricist assumptions can be problematic due to the emphasis placed on the social setting where the research takes place. Any inferred interpretation is only valid within the specific setting and cannot be generalized to a wider context (Lewis and Ritchie, 2003).

This does not reduce the potential of research in the neo-empiricist paradigm, but influences the interpretation of results (Strauss, 1987). Form-oriented content analyses are based on statistical inference, where generalizability derives from sampling. On the contrary, meaning-oriented content analyses rely on logical inference, what Dumay and Cai (2015) 
refer to as abductive inference. This is based on rational and rigorous reasoning, which is used to propose an 'inductively generated and tested theoretical model' (Mitchell, 1983, p. 190). Abduction is a form of inference 'that goes from data describing something to a hypothesis that best explain or accounts for the data' (Josephson and Josephson, 1996). In this perspective, the conclusion of an abduction is 'logically justified' and contributes to generate knowledge by the force of its argument (Peng and Reggia, 2012).

Triangulation offers a possible way to improve intellectual capital research quality and overcome possible mistrust towards logical inference and meaning-oriented studies (Webb et al., 1966). Triangulation 'entails the contingent use of multiple researchers, multiple primary and secondary data sources and collection methods to cross-reference and substantiate the objectivity of findings by demonstrating their convergence and consistency of meaning' (Johnson et al., 2006, p. 139). The use of more than one method or multiple data sources strengthens the validation process as it ensures that the results obtained do not only depend on a specific dataset or method, thus they 'are valid and not a methodological artifact' (Bouchard, 1976, p. 268).

In their review of intellectual capital studies using content analysis, Dumay and Cai (2015) document little attention to validity by researchers. Gately and Cunningham (2014) use qualitative interviewing and qualitative content analysis to investigate relational capital. Buhr (1998) provides an example of triangulation in the field of environmental disclosure, where three research methods - historiography, interviews and content analysis - are used to develop a fuller and richer picture of environmental performance and related annual report disclosure in a case study.

\section{ASSESSING INTELLECTUAL CAPITAL DISCLOSURE: OVERCOMING THE OVERLAP BETWEEN QUALITY AND QUANTITY}

To assess companies' intellectual capital disclosure, extant research has mainly focused on disclosure frequency and volume, under the assumption that the frequency or volume of disclosure signals how important the writers of a report consider the issue to be (Unerman, 2000). Accordingly, the amount of space (whether in terms of words, sentences, paragraphs, and so on) devoted to intellectual capital disclosure has become the usual focus of content analyses (Beattie and Thomson, 2007).

Over time, many authors have highlighted the limitations related to the adoption of the volume/frequency of disclosure as a proxy for a complex, 
multifaceted concept such as disclosure quality (Beattie et al., 2004). For instance, several authors have highlighted that disclosure practices may differ not only in regard to the quantity of information released but also in terms of the modalities of presentation (Beretta and Bozzolan, 2008; Chatterjee et al., 2008). In the field of intellectual capital disclosure, this issue is particularly important, as 'the volume of disclosure is potentially misleading when it is the credibility and quality of disclosure that is important' (Beattie and Thomson, 2007, p. 141).

This awareness has resulted in the development of disclosure measures that take into account the nature of disclosure, distinguishing between quantitative and qualitative information. Guthrie et al. (2006), in their examination of voluntary reporting of intellectual capital by listed companies in Australia and Hong Kong, use an intellectual capital coding framework including 24 items. Each item was classified according to a four-element scheme: 0 if the item does not appear in the annual report; 1 if the item appears in a discursive form; 2 if the item is expressed in numerical terms; and 3 if it is quantified in dollar (currency) terms. Discussing their results, the authors noticed that nearly every instance of intellectual capital reporting involved expression in discursive rather than numerical terms, and explain this result in terms of 'the difficulty involved in trying to quantify what is, in many instances, essentially a qualitative item' (Guthrie et al., 2006, p. 268). They add that 'the low incidence of quantitative expressions of intellectual capital items seems to confirm the widely-held view that companies are not motivated to assign dollar values to intellectual capital' (Guthrie et al., 2006, p. 268).

Bozzolan et al. (2003) adopt a similar approach based on a threeelement scheme that classifies items into three categories: 0 for the absence of the item; 1 for discursive information; and 2 for quantitative measures. Different to Guthrie et al. (2006), they use this framework as a weighting scheme, implicitly assuming that numerical information provides higherquality disclosure than discursive disclosure.

However, linking quality with quantitative information might be inappropriate in the intellectual capital context (Beattie and Thomson, 2007), in part due to the difficulties in quantifying certain intellectual capital items, as the above quotation from Guthrie et al. (2006) emphasizes. Moreover, narrative theory, taken up in management and organizational studies (Tenkasi and Boland, 1993), stresses the role of discursive information in accounting disclosure. Narratives are considered as storytelling competences aimed at both convincing others to devote funds and other crucial resources to the company, and building the tangible and intangible worth of the company (O'Connor, 2002). In the context of intellectual 
capital disclosure, the value added of storytelling is the ability to explain the connections among key tangible and intangible factors (Mouritsen et al., 2001; Nielsen, 2010). Holland (2004, p. 47) maintains that 'intangibles that were invisible to outside monitors, were connected via the story to more visible intangibles and to tangibles as well as to output and performance measures'.

In light of this, the distinction between narrative and quantitative information is not sufficient to assess intellectual capital disclosure. A focus on narrative is needed to understand whether and to what extent it is able to convey intellectual capital information about a company. In keeping with linguistic studies, narrative can consist of both: effective narrative (Rhee and Lee, 2003), that is, information that focuses on relevant matters; and mere rhetoric, that is, 'words without commitment' (Eccles et al., 1992). Rhetoric should be weighted less when it is provided in large volume without commitment (Toms, 2002). Beattie and Thomson (2007) argue that intellectual capital research has never discussed this issue, paying no attention to the contents included in intellectual capital narrative.

Intellectual capital disclosure studies have also been criticized by Mouritsen et al. (2001) for the widespread use of the three-way model that splits intellectual capital into human capital, organizational (structural) capital and customer capital. The authors notice that this model assumes a strict separation between the three categories that is questionable, although it is valuable from a measurement perspective. The three elements of intellectual capital are complements, as they 'are part of a network of things and people that coproduce the effects of the whole network' (Mouritsen et al., 2001). Limiting the assessment to these three categories does not allow for the appraisal of the 'full' intellectual capital activated by companies, because a critical element, the interaction among factors (Roos et al., 1997), is left out. Therefore, the three-way model is unable to capture synergies that exist across the categories (Beattie and Smith, 2013) and that create what is known as the fourth intellectual capital element, the connectivity capital (Habersam and Piber, 2003; Bjurström and Roberts, 2007).

Moving from this criticism, Bini et al. (2016a) propose a new approach for assessing intellectual capital narratives grounded on two qualitative aspects: focus and connectivity. The former is aimed at identifying effective intellectual capital narrative based on the assumption that intellectual capital narratives should illustrate how intangible resources actively contribute to the company's value creation process (Björkdahl, 2009; Chesbrough and Rosenbloom, 2002). Thus, focused intellectual capital narratives exclude any generic description concerning intangible 
resources, as well as any intention, project or policy that is not referred to in terms of specific implemented activities and/or results.

The second dimension, connectivity, relies on the assumption that intellectual capital narrative should communicate the connections among key tangible and intangible factors, enabling market participants to gain an integrated view of that process over time (Holland, 2004). Therefore, this second aspect focuses on the presence of linkages within narratives, linkages that illustrate interactions, synergies, causal relations between intangibles or between intangible and tangible resources. Taken together these two aspects aim to assess the extent to which the story disclosed by companies is able to highlight the causal relationships among the elements involved in the value creation processes, presenting intellectual capital not 'on hold', but 'in action' (Chiucchi, 2013).

Bini et al. (2016a) use this framework to content analyse the disclosure included in the annual reports of 35 listed UK companies. To reduce subjective judgements, the authors develop a detailed scheme of coding to identify focused information. Analogously, they define specific rules to identify the linkages among the information (connectivity dimension). More precisely, they consider both explicit connections, expressed by connectives (that is, joining words used to connect phrases together into longer sentences) and implicit connections, provided by the text construction (Bini et al., 2016a, p. 91). Moreover, for both the aspects, they provide some practical examples of classifications, in keeping with Carney (1972) who recommends the use of illustrative examples to explain a coding framework. Results show that less than half of the information provided focuses on value creation, and companies rarely illustrate how resources, competences and activities are connected together to create value.

This first attempt to propose an alternative way to assess intellectual capital disclosure should stimulate researchers to break the conventional rules underpinning established methods. This seems particularly important as intellectual capital research has been criticized for producing controversial and inconclusive contributions (Abeysekera, 2006; Dumay and Cai, 2014).

\section{MOVING INTELLECTUAL CAPITAL DISCLOSURE RESEARCH FORWARD}

Intellectual capital disclosure has been and remains a main research topic in the field of accounting. Even though the project of an intellectual capital statement has been abandoned (Dumay, 2016, p. 168), companies keep communicating intellectual capital information. This offers future 
research opportunities, including both voluntary and mandatory disclosure. On the one hand, the growing popularity of integrated reporting among companies provides an opportunity to improve the knowledge about voluntary disclosure practices. On the other hand, the gradual rise of regulations for non-financial information poses new and interesting research challenges.

To date, most research on intellectual capital disclosure has been based on voluntary disclosure theory, as intellectual capital information has been provided by companies mainly on a voluntary basis. The issue of the Directive 2014/95 calls for research to shed light on intellectual capital regulation. Previous studies document that both voluntary and mandatory non-financial disclosure suffer from less credibility compared to quantitative financial information (Hirst et al., 1995; Hodge et al., 2006). This is related to the unavoidable discretion which characterizes non-financial information and gives managers incentives to report in an opportunistic way. According to Cormier et al. (2009, p. 73), 'firms may play on information attributes, such as precision level, to mitigate an external audience's tendency to discount the credibility of its discretionary disclosures and thus, enhance the persuasiveness and effectiveness of social and human capital disclosures'. In this vein, intellectual capital research may offer a relevant contribution to both companies which aim to enhance their disclosure, and regulators who need to guarantee high-level disclosure quality and identify opportunistic behaviours. Since intellectual capital disclosure is mainly narrative in nature, the content analysis technique is an appropriate tool of investigation.

On the other hand, the increasing number of companies issuing an integrated report (Gibassier et al., 2019) calls for research that looks at intellectual capital disclosure within integrated reporting to investigate, among other issues, its quality, its objective and its tone. High-quality content analyses, based on both form-oriented and meaning-oriented approaches, can contribute to better understand intellectual capital disclosure communicated by integrated reporting and its effectiveness in addressing stakeholders' information needs.

Lastly, communication devices represent another opportunity to enrich intellectual capital disclosure research. Content analysis studies largely focus on annual reports (Dumay, 2014). However, it is acknowledged that companies also use other channels to convey intellectual capital information, such as the company's website (Waters et al., 2009). To date, very few studies have focused on different communication tools. This includes information released via social media (Pisano et al., 2017; Lardo et al., 2017), initial public offering (IPO) prospectuses (Garanina and Dumay, 2017), earnings announcements and conference calls (Graaf, 2013), and 
analyst reports (García-Meca and Martínez, 2007; Abhayawansa and Guthrie, 2016).

Research opportunities can be identified in meaning-oriented content analysis, which has received little attention to date despite it being deemed the most useful in intellectual capital disclosure research (Guthrie, 2014). Beyond positivism and content analysis, other paradigms and methodologies should be explored to investigate intellectual capital disclosure (Roslender, 2004). For instance, Nielsen and Madsen (2009) use critical realism and discourse analysis to discuss the issue of transparency in intellectual capital reporting. Alternative instruments to investigate intellectual capital disclosure can be drawn from other disciplines, such as sociology and linguistics (Beattie, 2014).

Pollach (2012) argues that the process of opening up to new methodologies is still in its infancy in the accounting field. In this regard, corpus linguistics (Tognini-Bonelli, 2001) could represent an appealing tool for studying intellectual capital disclosure. Corpus linguistics is based on the perspective that a text is an integral part of its context, as communication cannot exist in isolation, detached from a specific environment (Sinclair, 1991). This technique combines both automated quantitative analysis, which usually focuses on the most frequent words in a text (keywords), and qualitative discourse analysis aimed at interpreting the keywords within the contextual words (Sinclair, 1991). These characteristics make corpus linguistics a flexible device that may be used in both positivist analyses of texts, and qualitative analyses anchored to other paradigms (Bini et al., 2016b).

Corpus linguistics has been used in the accounting field by Zappettini and Unerman (2016, p. 521) to explore sustainability disclosure in integrated reports with the aim to understand 'how discourses of sustainability have been recontextualized into financial and economic macro discourses and how different intertextual/interdiscursive relations have played out in linguistic constructions of "sustainability".

Recent reviews show that there is much work to be done to increase the quality of intellectual capital disclosure research (Dumay and Cai, 2014, 2015). Researchers seem to be reluctant to leave the comfort zone of descriptive and replicative analyses, which in many cases are methodologically questionable (Abeysekera, 2006).

Methodological rigour starts with an in-depth knowledge of the content analysis technique as well as of the assumptions on which it is based. Content analysis studies rarely discuss the research paradigm adopted, even though this strongly affects the development of the coding process, the evaluation criteria and the interpretation of findings. A more explicit explanation could be useful for researchers to guarantee the coherence of 
their research design within the paradigm adopted. Readers would benefit from a clear presentation of the framework in use as they can more easily interpret the results and identify the contribution of the work.

Additionally, the limitations of existing disclosure measures used to assess intellectual capital reveal that there is room for new approaches (Beattie et al., 2004). Bini et al. (2016a) propose alternative measures of intellectual capital narratives based on two key characteristics of intellectual capital disclosure: focus and connectivity. This approach could be used to assess intellectual capital disclosure with both form-oriented and meaning-oriented content analyses.

\section{REFERENCES}

Abeysekera, I. (2006), 'The project of intellectual capital disclosure: researching the research', Journal of Intellectual Capital, 7 (1), 61-77.

Abeysekera, I. and J. Guthrie (2005), 'An empirical investigation of annual reporting trends of intellectual capital in Sri Lanka', Critical Perspectives on Accounting, 16 (3), 151-163.

Abhayawansa, S. (2011), 'A methodology for investigating intellectual capital information in analyst reports', Journal of Intellectual Capital, 12 (3), 446-476.

Abhayawansa, S. and J. Guthrie (2014), 'Importance of intellectual capital information: a study of Australian analyst reports', Australian Accounting Review, 24 (1), 66-83.

Abhayawansa, S. and J. Guthrie (2016), 'Does intellectual capital disclosure in analysts' reports vary by firm characteristics?', Advances in Accounting, 35, 26-38.

Abrahamson, E. and C. Park (1994), 'Concealment of negative organizational outcomes: an agency theory perspective', Academy of Management Journal, 37 (5), 1302-1334.

Accounting Standards Board (2006), Reporting Statement: Operating and Financial Review, London.

Adams, C.A. (2015), 'The international integrated reporting council: a call to action', Critical Perspectives on Accounting, 27, 23-28.

Alvesson, M. and S. Deetz (2000), Doing Critical Management Research, London: SAGE.

Beattie, V. (2014), 'Accounting narratives and the narrative turn in accounting research: issues, theory, methodology, methods and a research framework', British Accounting Review, 46 (2), 111-134.

Beattie, V., McInnes, B. and S. Fearnley (2004), 'A methodology for analysing and evaluating narratives in annual reports: a comprehensive descriptive profile and metrics for disclosure quality attribute', Accounting Forum, 28, 205-326.

Beattie, V. and S.J. Smith (2013), 'Value creation and business models: refocusing the intellectual capital debate', British Accounting Review, 45 (4), 243-254.

Beattie, V., and S.J. Thomson (2007), 'Lifting the lid on the use of content analysis to investigate intellectual capital disclosures', Accounting Forum, 31 (2), 129-163.

Berelson, B. (1952), Content Analysis in Communication Research, Glencoe, IL: Free Press.

Beretta, S. and S. Bozzolan (2008), 'Quality versus quantity: the case of forward-looking disclosure', Journal of Accounting, Auditing and Finance, 23 (3), 333-376.

Bini, L., Dainelli, F. and F. Giunta (2016a), 'Business model disclosure in the Strategic Report', Journal of Intellectual Capital, 17 (1), 83-102.

Bini, L., Samson, C. and F. Giunta (2016b), 'Let the text talk: a corpus-driven analysis approach to investigate accounting narratives', European Journal of Economics, Finance and Administrative Sciences, 89, 81-96.

Björkdahl, J. (2009), 'Technology cross-fertilization and the business model: the case of integrating ICTs in mechanical engineering products', Research Policy, 38 (9), 1468-1477. 
Bjurström, E. and H. Roberts (2007), 'The principle of connectivity: networked assets, strategic capabilities and bundled outcomes', in C. Chaminade and B. Catasús (eds), Intellectual Capital Revisited: Paradoxes in the Knowledge Intensive Organization, Cheltenham, UK and Northampton, MA, USA: Edward Elgar Publishing, pp. 45-60.

Boland, R.J. and L.R. Pondy (1983), 'Accounting in organizations: a union of natural and rational perspectives', Accounting Organizations and Society, 8 (2/3), 223-234.

Bontis, N. (2003), 'Intellectual capital disclosure in Canadian corporations', Journal of Human Resource Costing and Accounting, 7 (1), 9-20.

Bouchard, T.J. (1976), 'Unobtrusive measures: an inventory of uses', Sociological Methods and Research, 4, 267-300.

Boyatzis, R.E. (1998), Transforming Qualitative Information: Thematic Analysis and Code Development, Thousand Oaks, CA: SAGE Publications.

Bozzolan, S., Favotto, F. and F. Ricceri (2003), 'Italian annual intellectual capital disclosure: an empirical analysis', Journal of Intellectual Capital, 4 (4), 543-558.

Brüggen, A., Vergauwen, P. and M. Dao (2009), 'Determinants of intellectual capital disclosure: evidence from Australia', Management Decision, 47 (2), 233-245.

Buhr, N. (1998), 'Environmental performance, legislation and annual report disclosure: the case of acid rain and Falconbridge', Accounting, Auditing and Accountability Journal, 11 (2), 163-190.

Campbell, D. and M.R.A. Rahman (2010), 'A longitudinal examination of intellectual capital reporting in Marks \& Spencer annual reports, 1978-2008', British Accounting Review, 42 (1), 56-70.

Canibano, L. (2018), 'Accounting and intangibles', Revista de Contabilidad, 21 (1), 1-6.

Carney, T.F. (1972), Content Analysis: A Technique for Systematic Inference from Communications, Winnipeg, MB: University of Manitoba Press.

Chatterjee, B., Tooley, S. and V. Fatseasa (2008), 'An analysis of the qualitative characteristics of management commentary reporting by New Zealand companies', 20th AsianPacific Conference on International Accounting Issues, 9-12 November, Paris.

Chen, M.C., Cheng, S.J. and Y. Hwang (2005), 'An empirical investigation of the relationship between intellectual capital and firms' market value and financial performance', Journal of Intellectual Capital, 6 (2), 159-176.

Cheng, M., Green, W., Conradie, P., Konishi, N. and A. Romi (2014), 'The international integrated reporting framework: Key issues and future research opportunities', Journal of International Financial Management and Accounting, 25 (1), 90-119.

Chesbrough, H. and R.S. Rosenbloom (2002), 'The role of the business model in capturing value from innovation: evidence from Xerox Corporation's technology spin-off companies', Industrial and Corporate Change, 11 (3), 529-555.

Chiucchi, M.S. (2013), 'Intellectual capital accounting in action: enhancing learning through interventionist research', Journal of Intellectual Capital, 14 (1), 48-68.

Cormier, D., Aerts, W., Ledoux, M.J. and M. Magnan (2009), 'Attributes of social and human capital disclosure and information asymmetry between managers and investors', Canadian Journal of Administrative Sciences, 26 (1), 71-88.

Craig, R., Lehman, G., Milne, M. and H. Tregidga (2010), 'Analysing the quality, meaning and accountability of organisational reporting and communication', call for papers, Accounting Forum.

Dilling, P.F. and P. Harris (2018), 'Reporting on long-term value creation by Canadian companies: a longitudinal assessment', Journal of Cleaner Production, 191, 350-360.

Dumay, J. (2014), ' 15 years of the journal of intellectual capital and counting: a manifesto for transformational IC research', Journal of Intellectual Capital, 15 (1), 2-37.

Dumay, J. (2016), 'A critical reflection on the future of intellectual capital: from reporting to disclosure', Journal of Intellectual Capital, 17 (1), 168-184.

Dumay, J., Bernardi, C., Guthrie, J. and P. Demartini (2016), 'September. Integrated reporting: a structured literature review', Accounting Forum, 40 (3), 166-185.

Dumay, J. and L. Cai (2014), 'A review and critique of content analysis as a methodology for inquiring into IC disclosure', Journal of Intellectual Capital, 15 (2), 264-290. 
Dumay, J. and L. Cai (2015), 'Using content analysis as a research methodology for investigating intellectual capital disclosure: a critique', Journal of Intellectual Capital, $16(1), 121-155$.

Eccles, R.G. and M.P. Krzus (2010), One Report: Integrated Reporting for a Sustainable Strategy, Hoboken, NJ: John Wiley \& Sons.

Eccles, R.G., Nohria, N. and J.D. Berkley (1992), Beyond the Hype: Rediscovering the Essence of Management, Boston, MA: Harvard Business School Press.

Flower, J. (2015), 'The international integrated reporting council: a story of failure', Critical Perspectives on Accounting, 27 (1), 1-17.

Garanina, T. and J. Dumay (2017), 'Forward-looking intellectual capital disclosure in IPOs: implications for intellectual capital and integrated reporting', Journal of Intellectual Capital, 18 (1), 128-148.

García-Meca, E. and I. Martínez (2007), 'The use of intellectual capital information in investment decisions: an empirical study using analyst reports', International Journal of Accounting, 42 (1), 57-81.

Gately, C. and J. Cunningham (2014), 'Building intellectual capital in incubated technology firms', Journal of Intellectual Capital, 15 (4), 516-536.

Gibassier, D., Adams, C.A. and T. Jérôme (2019), Integrated Reporting and the Capitals' Diffusion, Report published by the French Accounting Standard Setter (Autorité des Normes Comptables).

Goebel, V. (2015), 'Is the literature on content analysis of intellectual capital reporting heading towards a dead end?', Journal of Intellectual Capital, 16 (3), 681-699.

Graaf, J. (2013), 'Colouring the numbers - on the role of intellectual capital in financial reporting', Journal of Intellectual Capital, 14 (3), 376-394.

Guthrie, J. (2014), 'In defence of disclosure studies and the use of content analysis: a research note', Journal of Intellectual Capital, 15 (2), 291-292.

Guthrie, J.E. and R. Petty (2000), 'Intellectual capital: Australian annual reporting practices', Journal of Intellectual Capital, 1 (3), 241-251.

Guthrie, J., Petty, R. and F. Ricceri (2006), 'The voluntary reporting of intellectual capital: comparing evidence from Hong Kong and Australia', Journal of Intellectual Capital, 7 (2), 254-271.

Guthrie, J., Petty, R., Yongvanich, K. and F. Ricceri (2004), 'Using content analysis as a research method to inquire into intellectual capital reporting', Journal of Intellectual Capital, 5 (2), 282-293.

Habersam, M. and M. Piber (2003), 'Exploring intellectual capital in hospitals: two qualitative case studies in Italy and Austria', European Accounting Review, 12 (4), 753-779.

Hirst, D., Koonce, L. and P. Simko (1995), 'Investor reactions to financial analysts' research reports', Journal of Accounting Research, 33 (2), 335-351.

Hodge, F., Hopkins, P.E. and J. Pratt (2006), 'Management reporting incentives and classification credibility: the effects of reporting discretion and reputation', Accounting, Organizations and Society, 31 (7), 623-634.

Holland, J. (2004), Corporate Intangibles, Value Relevance and Disclosure Content, Edinburgh: Institute of Chartered Accountants of Scotland.

Holsti, O.R. (1969), Content Analysis for the Social Sciences and Humanities, Reading, MA: Addison-Wesley.

Husin, N.M., Hooper, K. and K. Olesen (2012), 'Analysis of intellectual capital disclosure - an illustrative example', Journal of Intellectual Capital, 13 (2), 196-220.

International Integrated Reporting Council (IIRC) (2013a), Integrated Reporting - The Pilot Programme 2013 Yearbook: Business and Investors Explore the Sustainability Perspective of Integrated Reporting, London: International Integrated Reporting Council.

International Integrated Reporting Council (IIRC) (2013b), The Integrated IR Framework, London: International Integrated Reporting Council.

Jackson, N. and P. Carter (1993), "Paradigm wars": a response to Hugh Willmott', Organization Studies, 14 (5), 721-725. 
Johnson, P., Buehring, A., Cassell, C. and G. Symon (2006), 'Evaluating qualitative management research: towards a contingent criteriology', International Journal of Management Reviews, 8 (3), 131-156.

Johnson, P. and J. Duberley (2000), Understanding Management Research: An Introduction to Epistemology, London: SAGE.

Josephson, J.R. and S.G. Josephson (eds) (1996), Abductive Inference: Computation, Philosophy, Technology, Cambridge: Cambridge University Press.

Kamath, B. (2017), 'Determinants of intellectual capital disclosure: evidence from India', Journal of Financial Reporting and Accounting, 15 (3), 367-391.

Keenan, J. and M. Aggestam (2001), 'Corporate governance and intellectual capital: some conceptualisations', Corporate Governance: An International Review, 9 (4), 259-275.

Krippendorff, K. (2013), Content Analysis: An Introduction to its Methodology, Thousand Oaks, CA: SAGE.

Lardo, A., Dumay, J., Trequattrini, R. and G. Russo (2017), 'Social media networks as drivers for intellectual capital disclosure: evidence from professional football clubs', Journal of Intellectual Capital, 18 (1), 63-80.

Lewis, J. and J. Ritchie (2003), 'Generalizing from qualitative research', in J. Ritchie and J. Lewis (eds), Qualitative Research Practice, London: SAGE, pp. 263-287.

Li, J., Pike, R. and R. Haniffa (2008), 'Intellectual capital disclosure and corporate governance structure in UK firms', Accounting and Business Research, 38 (2), 137-159.

Maniora, J. (2017), 'Is integrated reporting really the superior mechanism for the integration of ethics into the core business model? An empirical analysis', Journal of Business Ethics, 140 (4), 755-786.

Marr, B. and J. Chatzkel (2004), 'Intellectual capital at the crossroads: managing, measuring, and reporting of IC', Journal of Intellectual Capital, 5 (2), 224-229.

Melloni, G. (2015), 'Intellectual capital disclosure in integrated reporting: an impression management analysis', Journal of Intellectual Capital, 16 (3), 661-680.

MERITUM (2002), Guidelines for Managing and Reporting on Intangibles, Tucson, AZ: TSER Programme, MERITUM.

Merkl-Davies, D.M., Brennan, N.M. and P. Vourvachis (2011), 'Text analysis methodologies in corporate narrative reporting research', working paper presented at 23rd CSEAR International Colloquium, St Andrews, UK.

Milne, M.J. and R.W. Adler (1999), 'Exploring the reliability of social and environmental disclosures content analysis', Accounting, Auditing and Accountability Journal, 12 (2), 237-256.

Mitchell, J.C. (1983), 'Case and situational analysis', Sociological Review, 31, 187-211.

Mouritsen, J., Bukh, P.N., Flagstad, K., Thorbjørnsen, S., Johansen, M.R., et al. (2003), Intellectual Capital Statements in Practice - Inspiration and Good Advice, Copenhagen: Danish Ministry of Science, Technology and Innovation.

Mouritsen, J., Larsen, H.T. and P.N. Bukh (2001), 'Intellectual capital and the "capable firm": narrating, visualising and numbering for managing knowledge', Accounting, Organisations and Society, 26 (7), 735-762.

Neuendorf, K.A. (2002), The Content Analysis Guidebook, Thousand Oaks, CA: SAGE Publications.

Nielsen, C. (2010), 'Conceptualizing, analyzing and communicating the business model', Working Paper No. 2, Department of Business Studies, Aalborg University, Denmark.

Nielsen, C. and M.T. Madsen (2009), 'Discourses of transparency in the intellectual capital reporting debate: moving from generic reporting models to management defined information', Critical Perspectives on Accounting, 20 (7), 847-854.

O'Connor, E. (2002), 'Storied business: typology, intertextuality, and traffic in entrepreneurial narrative', Journal of Business Communication, 39 (1), 36-54.

Painter-Morland, M. (2006), 'Triple bottom-line reporting as social grammar: integrating corporate social responsibility and corporate codes of conduct', Business Ethics: A European Review, 15 (4), 352-364. 
Peng, Y. and J.A. Reggia (2012), Abductive Inference Models for Diagnostic Problem-Solving, New York: Springer Science \& Business Media.

Pisano, S., Lepore, L. and R. Lamboglia (2017), 'Corporate disclosure of human capital via LinkedIn and ownership structure: An empirical analysis of European companies', Journal of Intellectual Capital, 18 (1), 102-127.

Pollach, I. (2012), 'Taming textual data: the contribution of corpus linguistics to computeraided text analysis', Organizational Research Methods, 15 (2), 263-287.

Rhee, S.K. and S.Y. Lee (2003), 'Dynamic change of corporate environmental strategy: rhetoric and reality', Business Strategy and the Environment, 12 (3), 175-190.

Roos, G., Ross, G., Edvinsson, L. and N.C. Dragonetti (1997), Intellectual Capital: Navigating in the New Business Landscape, Houndmills: Macmillan Business.

Roslender, R. (2004), 'Accounting for intellectual capital: rethinking its theoretical underpinnings', Measuring Business Excellence, 8 (1), 38-45.

Schaper, S., Nielsen, C. and R. Roslender (2017), 'Moving from irrelevant intellectual capital (IC) reporting to value-relevant IC disclosures: key learning points from the Danish experience', Journal of Intellectual Capital, 18, 81-101.

Sinclair, J. (1991), Corpus, Concordance, Collocation, Oxford: Oxford University Press.

Smith, M. and R. Taffler (2000), 'The chairman's statement. A content analysis of discretionary narrative disclosures', Accounting, Auditing and Accountability Journal, 13 (5), 624-646.

Steenkamp, N. and D. Northcott (2007), 'Content analysis in accounting research: the practical challenges', Australian Accounting Review, 17 (43), 12-25.

Strauss, A. (1987), Qualitative Analysis for Social Scientists, Cambridge: Cambridge University Press.

Striukova, L., Unerman, J. and J. Guthrie (2008), 'Corporate reporting of intellectual capital: evidence from UK companies', British Accounting Review, 40 (4), 297-313.

Sveiby, K.E. (1997), The New Organizational Wealth: Managing and Measuring KnowledgeBased Assets, Oakland, CA: Berrett-Koehler Publishers.

Tenkasi, R. and R. Boland (1993), 'Locating meaning making in organizational learning: the narrative basis of cognition', in R. Woodman and W. Pasmore (eds), Research on Organizational Change and Development (Vol. 7), Greenwich, CT: JAI Press, pp. 77-103.

Tognini-Bonelli, E. (2001), Corpus Linguistics at Work, Amsterdam: John Benjamins.

Toms, J.S. (2002), 'Firm resources, quality signals and the determinants of corporate environmental reputation: some UK evidence', British Accounting Review, 34 (3), $257-282$.

Unerman, J. (2000), 'Methodological issues: reflections on quantification in corporate social reporting content analysis', Accounting, Auditing and Accountability Journal, 13 (5), 667-681.

Vafaei, A., Taylor, D. and K. Ahmed (2011), 'The value relevance of intellectual capital disclosures', Journal of Intellectual Capital, 12 (3), 407-429.

Vandemaele, S.N., Vergauwen, P.G.M.C. and A.J. Smits (2005), 'Intellectual capital disclosure in The Netherlands, Sweden and the UK: a longitudinal and comparative study', Journal of Intellectual Capital, 6 (3), 417-426.

Waters, R.D., Burnett, E., Lamm, A. and J. Lucas (2009), 'Engaging stakeholders through social networking: how non-profit organizations are using Facebook', Public Relations Review, 35 (2), 102-106.

Webb, E.J., Campbell, D.T., Schwartz, R.D. and L. Sechrest (1966), Unobtrusive Measures: Non-reactive Research in the Social Sciences, Chicago, IL: Rand McNally.

Weber, R.P. (1990), Basic Content Analysis (2nd edn), Newbury Park, CA: SAGE Publications.

Welker, M. (1995), 'Disclosure policy, information asymmetry and liquidity in equity markets', Contemporary Accounting Research, 11, 801-828.

Whiting, R.H. and J.C. Miller (2008), 'Voluntary disclosure of intellectual capital in New Zealand annual reports and the hidden value', Journal of Human Resources Costing and Accounting, 12 (1), 26-50. 
Whiting, R.H. and J. Woodcock (2011), 'Firm characteristics and intellectual capital disclosure by Australian companies', Journal of Human Resource Costing and Accounting, 15 (2), 102-126.

Zappettini, F. and J. Unerman (2016), “Mixing" and "bending": the recontextualisation of discourses of sustainability in integrated reporting', Discourse and Communication, 10 (5), $521-542$. 